\title{
ANALISIS VOLUME PERDAGANGAN SAHAM PERBANKAN BUMN YANG TERDAFTAR DI BURSA EFEK INDONESIA BERDASARKAN VARIABEL MAKRO EKONOMI
}

\author{
Analysis of Stock Trading Volume of state-owned companies in banking sector which are \\ listed in Indonesia Stock Exchange based on Macroeconomic Variables
}

Wiwik Wulandari ${ }^{1}$, Sri Andriani ${ }^{1}$, Muhammad Nurjihadi ${ }^{2}$

${ }^{1}$ Program Studi Manajemen, Fakultas Ekonomi dan Bisnis, Universitas Teknologi Sumbawa

${ }^{2}$ Program Studi Ekonomi Pembangunan, Fakultas Ekonomi dan Bisnis, Universitas Teknologi Sumbawa

*) E-mail: Wiwikwulandari079@gmai.com

ABSTRACT

This study aims to analyze the effects of inflation, exchange rate, and the BI rate on stock trading volume of stateowned companies in banking sector (BUMN) in Indonesia Stock Exchange (BEI) in the monthly period of 2011 to 2015. The population in this study are four state-owned companies in banking sector listing in BEI. The sampling method used is saturated sampling technique, which is obtained four banking sector companies; BRI, BNI, BTN, and Bank Mandiri. analysis of the data is conducted by panel data regression analysis which consists of t-test, $F$ test, and test of determination. The results showed that inflation has no significant effect on the volume of stock trading and exchange rates, while the BI rate showed a significant influence on the volume of stock trading. On the other hand, all vavriables (inflation, exchange rates and the BI rate together) have a significant effect on the bank stock trading volume. The value of $R$ Square overalls at 0.0481, which means that inflation, exchange rate, and the BI rate has a causal relationship with banking stocks trade volume amounted to $4.81 \%$ and the remaining $95.19 \%$ is explained by other variables not examined in this study.

Keywords: Inflation, exchange rate, the BI rate, Stock Trading Volume, Multiple Data Panel.

\section{ABSTRAK}

Penelitian ini bertujuan untuk menganalisis pengaruh inflasi, kurs, dan BI rate terhadap volume perdagangan saham pada perusahaan sektor perbankan BUMN di Bursa Efek Indonesia (BEI) pada periode bulanan dari 20112015. Populasi dalam penelitian ini sebanyak 4 perusahaan sektor perbankan BUMN yang listing di BEI. Metode pengambilam sampel dengan teknik sampling jenuh, maka diperoleh 4 perusahaan sektor perbankan BUMN yaitu BRI, BNI, BTN dan Bank Mandiri. Analisis data dalam penelitian ini menggunakan analisis regresi data panel yang terdiri dari uji t, uji f dan uji determinasi. Hasil penelitian secara parsial menunjukan inflasi tidak berpengaruh signifikan terhadap volume perdagangan saham, kurs dan BI rate menunjukkan adanya pengaruh signifikan terhadap volume perdagangan saham. Secara simultan menunjukan adanya pengaruh yang signifikan antara inflasi, kurs dan BI rate terhadap volume perdagangan saham perbankan. Nilai $R$ Square overall sebesar 0.0481, yang artinya inflasi, kurs, dan BI rate mempunyai hubungan kausalitas dengan volume perdagangan saham perbankan sebesar $4.81 \%$ dan sisanya sebesar $95.19 \%$ dijelaskan oleh variabel lain yang tidak diteliti dalam penelitian ini.

Kata Kunci : Inflasi, Kurs, BI rate, Volume Perdagangan Saham, Regresi Data Panel.

\section{Pendahuluan}

Perekonomian suatu negara tidak lepas dari peran para pemegang dana, dan erat hubungannya dengan investasi. Sebagai negara yang sedang berkembang,
Indonesia membutuhkan adanya modal atau dana dalam jumlah yang besar sebanding dengan pertumbuhan yang telah ditargetkan. Dalam hal ini, 
pasar modal mempunyai peranan yang strategis dalam perekonomian Indonesia (Atik, 2012:1).

Menurut Setyowati (2007:3), dalam rangka mempercepat perkembangan pasar modal di Indonesia, perbankan memiliki peran yang sangat penting atau dikatakan strategis, karena bank-bank di Indonesia selain berfungsi sebagai bank umum juga sebagai bank investasi, sehingga pihak perbankan diijinkan untuk menjamin pengeluaran saham, obligasi dan juga menjadi pedagang suratsurat berharga.

Menurut Husnan dalam Maryanne (2009:15), pasar modal memiliki peran yang cukup penting bagi pembangunan ekonomi yaitu sebagai salah satu sumber pembiayaan eksternal bagi dunia usaha dan wahana investasi bagi masyarakat. Sebelum melakukan investasi di pasar modal para investor mencari pertimbangan mengenai situasi pergerakan harga saham di pasar modal saat itu. Oleh karena itu para pemilik dana (investor) perlu mencari tahu apa saja yang mempengaruhi pergerakan harga saham. Faktor lainnya yang mempengaruhi harga saham adalah volume perdagangan saham (Stock Trading Volume). Menurut Nasution (2014:3), volume perdagangan saham berpengaruh positif terhadap harga saham, artinya ketika volume perdagangan saham turun maka harga saham akan menurun pula, begitu pula sebaliknya.

Volume perdagangan saham merupakan perbandingan jumlah saham perusahaan yang diperdagangkan pada waktu $t$ dengan jumlah saham perusahaan yang beredar pada waktu t. Volume perdagangan saham adalah banyaknya lembaran saham suatu emiten yang diperjualbelikan di pasar modal setiap hari dengan tingkat harga yang disepakati oleh pihak penjual dan pembeli saham melalui perantara perdagangan saham di pasar modal. Mubarik dan Javid (2009:2) mengungkapkan dalam pasar saham volume perdagangan merupakan informasi penting, karena volume perdagangan menggambarkan pergerakan harga saham. Sehingga volume perdagangan saham dapat dikatakan sebagai hal yang penting bagi seorang investor, karena menggambarkan kondisi efek yang diperjualbelikan di pasar modal (Wiyani dalam Nasution, 2014:17).

Dalam keputusan berinvestasi biasanya investor memperhatikan besarnya risiko yang akan dihadapi dengan keuntungan yang diharapkan. Risiko-risiko ini dapat muncul dari pergolakan pasar, kondisi lingkungan usaha dan situasi ekonomi makro pada umumnya. Terlebih jika ingin berinvestasi di pasar modal, maka kondisi ekonomi makro harus diperhatikan jika tidak ingin mengalami kerugian. Hal ini diperlukan sebagai suatu faktor bagi investor mengambil keputusan investasinya. Kondisi ekonomi makro yang berpengaruh dengan pasar modal adalah inflasi, tingkat suku bunga bank indonesia (BI rate), dan nilai tukar rupiah terhadap US. dollar (Jonathan, 2013:1)

Seperti yang diungkapkan Sweneey et al dalam Alaganar dan Bhar (2003:39) perubahan suku bunga dapat mempengaruhi nilai perusahaan sektor keuangan. Salah satunya resiko yang muncul dikarenakan kewajiban perusahaan yang sudah jatuh tempo. Dengan demikian, ada berbagai faktor yang mempengaruhi sektor keuangan termasuk didalamnya yaitu suku bunga. Beberapa peneliti sebelumnya telah melakukan penelitian tentang pengaruh inflasi, kurs, dan BI rate terhadap volume perdagangan saham. Penelitian yang dilakukan Pramaditya (2008:64) dengan judul pengaruh SBI, nilai tukar kurs AS (USD), dan inflasi terhadap volume perdagangan saham perbankan yang terdaftar di Bursa Efek Indonesia periode 20042006. Jonathan (2013:4) melakukan penelitian dengan judul analisa pengaruh suku bunga, inflasi, dan kurs terhadap volume transaksi pada Index LQ45 periode penelitian dilakukan pada tahun 20072012. Kant (2011:371) melakukan penelitian dengan judul testing of relationship between stock return and trading volume in India. Dan Bakhromov (2011:149) juga melakukan penelitian dengan judul the exchange rate volatility and the trade balance: case of uzbekistan. Dari beberapa penelitian tersebut menunjukan hasil yang berbeda-beda (tidak konsisten).

Penelitian ini didasarkan pada perbedaan hasil penelitian terdahulu dan teori tentang inflasi. Inflasi adalah suatu keadaan dimana terjadi perubahan kenaikan harga barang dan jasa secara serentak dan menyeluruh dan terjadi dalam keadaan yang terusmenerus berlanjut, tidak hanya terjadi pada suatu waktu saja (Jonathan, 2013:1). Gambar 1 berikut menunjukan hubungan inflasi, suku bunga bank indonesia (BI rate), dan nilai tukar terhadap volume perdagangan saham PT. Bank Rakyat Indonesia tbk. Tahun 2015-2016. 


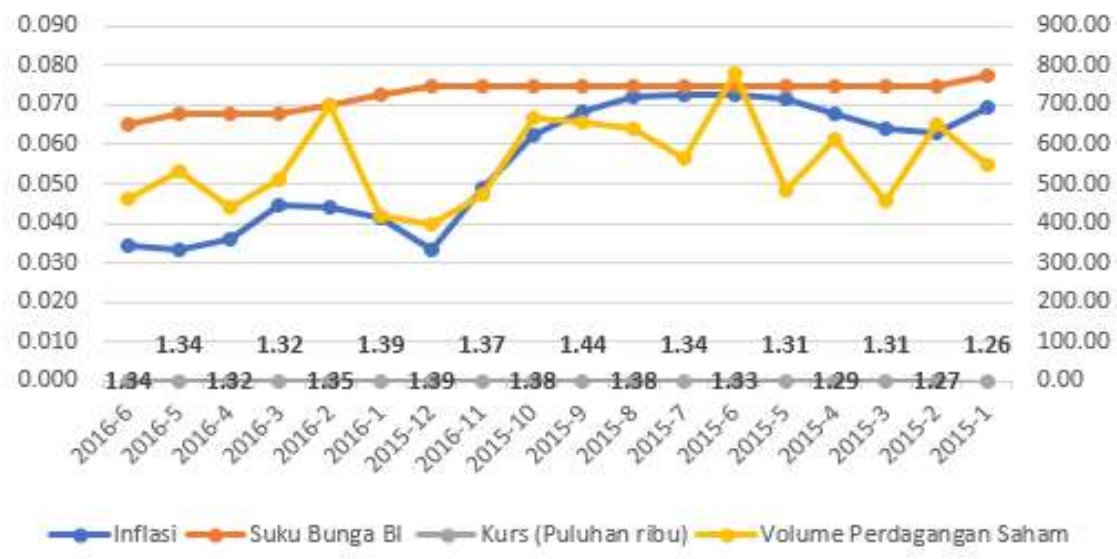

Gambar 1. Data inflasi, suku bunga bank indonesia (BI rate), dan nilai tukar terhadap volume perdagangan saham PT. Bank Rakyat Indonesia tbk. Tahun 2015-2016 (Bank Indonesia, 2017)

Kondisi yang tidak konsisten dengan teori ini terlihat pada gambar 1 dimana penurunan inflasi, dan BI rate tidak diikuti dengan meningkatnya volume perdagangan saham. Dan meningkatnya kurs USD tidak diikuti dengan menurunnya volume perdagangan saham.

Dari hal-hal tersebut di atas dapat dilihat betapa pentingnya peranan perbankan dalam usaha pengembangan pasar modal, dan berdasarkan beberapa penelitian terdahulu yang belum konsisten antara pengaruh faktor makro ekonomi terhadap volume perdagangan saham, dan mengacu kepada teori dan penelitian-penelitian tersebut, penulis tertarik untuk meneliti lebih lanjut tentang faktor makro ekonomi yang memengaruhi volume perdagangan saham dengan menggunakan perbankan BUMN yang terdaftar di Bursa Efek Indonesia sebagai sampel dengan judul "ANALISIS VOLUME PERDAGANGAN SAHAM PERBANKAN BUMN YANG TERDAFTAR DI BURSA EFEK INDONESIA BERDASARKAN VARIABEL MAKRO EKONOMI." Alasan memilih bank BUMN sebagai sampel dalam penelitian ini karena bank BUMN lebih dipercaya atau memiliki tingkat kepercayaan yang lebih tinggi dari nasabah dibandingkan dengan bank swasta. Hal ini dapat dilihat dari jumlah dana pihak ketiga yang dimiliki oleh bank BUMN tahun 2011-2015 lebih tinggi dibandingkan dengan bank swasta.Berdasarkan uraian tersebut maka dapat dirumuskan tujuan penelitian sebagai berikut:

1. Untuk mengetahui pengaruh inflasi terhadap volume perdagangan saham perbankan di Bursa Efek Indonesia tahun 2011- 2015.

2. Untuk mengetahui pengaruh nilai tukar AS terhadap volume perdagangan saham perbankan di Bursa Efek Indonesia tahun 2011-2015.

3. Untuk mengetahui pengaruh $\mathrm{BI}$ rate terhadap volume perdagangan saham perbankan di Bursa Efek Indonesia tahun 2011-2015.
4. Untuk mengetahui pengaruh inflasi, nilai tukar AS, dan BI rate terhadap volume perdagangan saham perbankan di Bursa Efek Indonesia tahun 20112015 .

\section{Metodologi Penelitian}

Dalam penelitian ini, penulis menggunakan metode penelitian kuantitatif deskriptif. metode kuantitatif adalah pendekatan yang menggunakan data yang berbentuk angka pada analisis statistik, penelitian ini merupakan penelitian yang bertujuan untuk mengetahui hubungan antara dua variabel atau lebih (Sugiyono, 2016:7), deskriptif adalah studi yang bertujuan untuk memperoleh deskripsi yang lengkap dan akurat dari suatu situasi (Kuncoro, 2011:3).

Adapun yang menjadi populasi dalam penelitian ini adalah lembaga perbankan Badan Usaha Milik Negara (BUMN) yang telah menjadi emiten di Bursa Efek Indonesia (BEI). Jumlah populasi dalam penelitian ini adalah sebanyak 4 Bank yaitu : Bank Rakyat Indonesia, Bank Mandiri, Bank Negara Indonesia, Bank BTN (Sahamok.com).

Teknik pemilihan sampel yang digunakan dalam penelitian ini adalah nonprobability sampling. Sugiyono (2013:95) nonprobability sampling adalah teknik pengambilan sampel yang tidak memberikan kesempatan yang sama bagi semua anggota populasi untuk dipilih menjadi sampel. Salah satu dari jenis teknik sampel ini yang digunakan oleh peneliti adalah sampling jenuh.

sampling jenuh merupakan teknik pengambilan sampel dengan menggunakan semua anggota populasi sebagai sampel. Hal ini dilakukan karena jumlah populasi dianggap kecil atau kurang dari 100 (Sugiyono, 2013:96). Adapun sampel yang dipilih dalam penelitian 
ini yaitu bank BUMN (BRI, BNI, BTN dan Bank Mandiri).

Dalam penelitian ini, peneliti menggunakan data sekunder dengan metode dokumentasi dan studi pustaka. Dengan metode dokumentasi peneliti mengumpulkan data yang dibutuhkan dari berbagai sumber. Sedangkan metode studi pustaka dilakukan sebagai pedoman dasar dalam menggunakan literatur, skripsi, jurnal nasional maupun internasional dan sumber lainnya untuk penelitian. Data yang digunakan dalam penelitian ini adalah data volume perdagangan saham perbankan, inflasi, nilai tukar rupiah terhadap dollar AS (kurs), dan suku bunga bank indonesia (BI rate) dari tahun 2011-2015.

Untuk mengetahui apakah inflasi, kurs, dan BI rate berpengaruh terhadap volume perdagangan saham, maka teknik analisa data dalam penelitian ini dilakukan dengan teknik analisis model regresi data panel. Data panel merupakan gabungan antara time-series dan cross-section (Suwardi, 2012:01). Formulasi untuk model pengaruh inflasi, kurs, dan BI rate terhadap volume perdagangan saham, diukur dengan persamaan sebagai berikut :

$$
\mathrm{Y}_{\mathrm{it}}=\alpha+\beta_{1 i t} X_{1 i t}+\beta_{2 i t} X_{2 i t}+\beta_{i t 3} X_{3 i t}+\mathrm{e}_{\mathrm{it}}
$$

Dimana:

$$
\begin{array}{ll}
\mathrm{Y} & =\text { volume perdagangan saham } \\
\alpha & =\text { konstanta } \\
\beta_{1}, \beta_{2}, \beta_{3} & \\
X_{1} & =\text { inflasi } \\
X_{2} & =\text { kurs } \\
X_{3} & =\text { BI } \text { rate } \\
i & =\text { perusahaan } \\
\mathrm{t} & =\text { waktu } \\
\mathrm{e} & =\text { error term }
\end{array}
$$

Sebelum melakukan analisis data panel, perlu dilakukan pemilihan metode analisis data untuk mendapatkan metode yang tepat. Analisis data yang dilakukan yaitu analisis model data panel dengan menggunakan 3 macam pendekatan yaitu Pooled least square, Pendekatan Fixed-effect (efek tetap) dan Pendakatan Random Effect (acak).

1) Pooled least square (PLS): Pendekatan pooled least square (PLS) atau sering disebut dengan common effect, merupakan pendekatan yang tidak memperhatikan dimensi atau runtut waktu meskipun data cross section digabungkan dengan data time series. PLS ini mengsumsikan koefisien slope kontan dan intersepnya sama antara individu baik time series maupun cross section (Setiawati dan Setiawan, 2012: 2).

2) Pendekatan efek tetap (Fixed-effect): Metode ini mengindiksikan bahwa individu ataupun perusahaan memiliki intersep yang berbeda akan tetapi memiliki slope regresi yang sama dari waktu ke waktu. Teknik ini mengestimasikan data panel menggunakan variabel dummy untuk membedakan intersepnya. Model ini juga sering disebut dengan LSDV (Least Square Dummy Variabel). Akan tetapi dengan memasukkan variabel dummy maka akan membawa konsekuensi yaitu berkurangnya derajat kebebasan sehingga efisiensi parameter menjadi berkurang.

3 ) Pendakatan acak (Random Effect): Random Effect Model adalah model etimasi regresi panel dengan asumsi koefisien slope konstan dan intersep berbeda antara individu dan antar waktu (Random Effect). Model ini mengasumsikan bahwa setiap individu atau perusahaan memiliki intersep yang berbeda yang merupakan variabel random.

\section{Teknik Pemilihan Model Regresi}

Untuk memilih metode estimasi yang tepat diantara ketiga jenis metode pendekatan yang tepat untuk digunakan, diperlukan beberapa tahapan pengujian, yaitu:

\section{1) Uji Chow}

Uji ini digunakan untuk mengetahui antara dua model yang dipilih untuk estimasi data, yaitu model Common Effect Model atau Fixed Effect Model (FEM). Hipotesis dalam uji chow sebagai berikut:

Ho : Common Effect atau Pooled least square (PLS)

Ha : Fixed Effect

Apabila hasil uji ini menunjukkan probabilitas $\mathrm{F}>0,05$ maka model yang dipilih adalah common effect. Sebaliknya, apabila probabilitas $\mathrm{F}<0,05$ maka model yang sebaiknya dipakai adalah fixed effect.

\section{2) Lagrange Multiplier (LM) Test}

Dilakukan untuk memilih model estimasi antara common effect atau random effect. Uji LM dilakukan ketika hasil pengujian Chow test menunjukkan bahwa Ho diterima. Hipotesis yang digunakan dalam pengujian yaitu:

Ho : Common Effect atau Pooled least square (PLS) Ha : Random Effect

Apabila hasil uji ini menunjukkan probabilitas $\mathrm{F}>0,05$ maka model yang dipilih adalah Common Effect atau Pooled least square (PLS). Sebaliknya, apabila probabilitas $\mathrm{F}<0,05$ maka model yang sebaiknya dipakai adalah Random Effect.

\section{3) Uji Hausman}

Hausman test adalah pengujian statistik untuk memilih apakah model Fixed Effect atau Random Effect yang paling tepat digunakan. Pengujian dilakukan dengan hipotesis berikut: 


\section{Ho: Random Effect Model}

\section{Ha: Fixed Effect Model}

Dasar penolakan terhadap hipotesis diatas adalah dengan membandingkan nilai statistik hausman dan nilai kritisnnya (Widarjono, 2009:240).

Jika nilai Prob $\mathrm{F}<\alpha$, maka tolak Ho

Jika nilai Prob $\mathrm{F}>\alpha$, maka terima Ho

\section{Uji Asumsi Klasik}

Selanjutnya untuk mengukur apakah data yang digunakan dalam penelitian ini bersifat BLUE (Best Linear Unbiased Estimator) atau tidak maka dilakukan uji asumsi klasik. Pengujian terhadap asumsi klasik bertujuan untuk mengetahui apakah suatu model regresi tersebut baik atau tidak jika digunakan untuk melakukan penaksiran. Suatu model dikatakan baik apabila data yang diuji bersifat BLUE, yaitu memenuhi asumsi klasik atau terhindar dari masalah-masalah multikolinieritas, heteroskedastisitas, dan autokorelasi ( Husen, 2011:140).

\section{Uji Hipotesis}

Selanjutnya dilakukan uji hipotesis, uji hipotesis ini dilakukan untuk mengetahui ada tidaknya pengaruh yang signifikan (baik positif atau negatif) antara variabel bebas : Kurs, Inflasi, BI rate terhadap variabel terikatnya yaitu Volume Perdagangan Saham. Dalam uji hipotesis ini dilakukan dengan uji t (secara parsial) dan uji F (secara simultan).

\section{Pengaruh inflasi terhadap volume perdagangan saham perbankan BUMN yang terdaftar di Bursa Efek Indonesia.}

Inflasi merupakan suatu fenomena ekonomi yang sering terjadi di Negara - Negara yang sedang berkembang. Masalah inflasi mudah dialami oleh sebagian besar Negara - Negara sedang berkembang dengan tingkat yang berbeda-beda. Inflasi secara umum adalah kenaikan harga secara terus menerus terhadap sejumlah barang.

Dengan inflasi yang tinggi maka biaya operasional perusahaan akan meningkat, sehingga laba yang diperoleh perusahaan akan menurun. Hal ini berdampak pada investor yang kurang tertarik untuk berinvestasi pada perusahaan tersebut, dengan demikian kondisi tersebut akan menyebabkan volume perdagangan saham menurun (Maryanne, 2009:46).

Penelitian empiris yang dilakukan oleh Pramaditya (2008) dengan judul pengaruh SBI, nilai kurs AS (USD), inflasi terhadap volume perdagangan saham yang terdaftar di Bursa Efek Indonesia Tahun 20042006 menyatakan bahwa inflasi berhubungan negatif dengan volume perdagangan saham.

Berdasarkan pernyataan-pernyataan di atas, maka hipotesis pertama penelitian ini adalah :

Ho1 : Inflasi berpengaruh signifikan terhadap volume perdagangan saham pada perusahaan sektor perbankan BUMN di Bursa Efek Indonesia.

Ha1 : Inflasi tidak berpengaruh signifikan terhadap volume perdagangan saham pada perusahaan sektor perbankan BUMN di Bursa Efek Indonesia.

\section{Pengaruh kurs terhadap volume perdagangan saham perbankan BUMN yang terdaftar di Bursa Efek Indonesia.}

Kurs atau nilai tukar mata uang merupakan harga mata uang terhadap mata uang lainnya. Salah satu pendekatan yang digunakan untuk menentukan nilai tukar mata uang yaitu pendekatan moneter. Dalam pendekatan moneter, nilai tukar mata uang didefinisikan sebagai harga dimana mata uang asing diperjualbelikan terhadap mata uang domestik dan harga tersebut berhubungan dengan penawaran dan permintaan uang. Nilai tukar valuta asing ditentukan dalam pasar valuta asing, yaitu pasar tempat berbagai mata uang yang berbeda diperjualbelikan. Jika ingin menukarkan satu mata uang nasional dengan mata uang lainnya, maka dapat dilakukan dengan berdasarkan nilai tukar yang berlaku (Samuelson, 2004: 306).

Rendahnya nilai tukar domestik dalam hal ini adalah rupiah terhadap valuta asing dalam hal ini dollar, akan menyebabkan rupiah semakin lemah diperdagangkan, sehingga kewajiban perusahaan (bank) dalam valuta asing akan semakin tinggi. Dengan demikian, bank akan semakin sulit dalam memenuhi kewajibannya, sehingga akan berdampak pada volume perdagangan saham bank yang rendah. Sebaliknya, semakin tinggi nilai tukar rupiah terhadap dollar maka akan menyebabkan rupiah semakin menguat diperdagangkan, sehingga bank akan semakin mudah dalam memenuhi kewajibannya, dan akan berdampak pada volume perdagangan saham yang meningkat.

Berdasarkan pernyataan-pernyataan di atas, maka hipotesis kedua penelitian ini adalah :

Ho2 : Kurs berpengaruh signifikan terhadap volume perdagangan saham pada perusahaan sektor perbankan BUMN di Bursa Efek Indonesia.

$\mathrm{Ha} 2$ : Kurs tidak berpengaruh signifikan terhadap volume perdagangan saham pada perusahaan sektor perbankan BUMN di Bursa Efek Indonesia. 
3. Pengaruh BI rate terhadap volume perdagangan saham perbankan BUMN yang terdaftar di Bursa Efek Indonesia.

$\mathrm{BI}$ rate merupakan suku bunga kebijakan yang mencerminkan sikap atau stance kebijakan moneter yang telah ditetapkan oleh Bank Indonesia. Tingkat suku bunga mencerminkan tingkat pembayaran atas pinjaman atau investasi lain, di atas perjanjian pembayaran kembali, yang dinyatakan dalam persentase yang telah ditetapkan bank. Bagi bank, bunga merupakan komponen pendapatan yang paling tinggi. Dari total pendapatan yang diterima bank, sebagian besar diperoleh dari bunga pinjaman. Suku bunga yang tinggi akan dapat menimbulkan tingginya volume tabungan masyarakat. Makin tinggi tingkat suku bunga yang ditawarkan bank mendorong masyarakat untuk lebih banyak menabung, artinya masyarakat cenderung akan mengurangi konsumsinya guna menambah saldo tabungan yang dimiliki (Maryanne, 2009:44).

Selain itu, suku bunga yang tinggi akan berdampak pada melonjaknya biaya modal perusahaan, sehingga perusahaan akan mengalami persaingan dalam investasi, artinya para investor cenderung memilih berinvestasi ke pasar uang atas tabungan dibandingkan pasar modal. Sebaliknya suku bunga yang rendah, baik suku bunga pinjaman maupun suku bunga simpanan akan berdampak pada menurunnya keinginan masyarakat untuk menabung. Sedangkan bagi perusahaan kondisi ini sangat menguntungkan karena perusahaan dapat mengambil kredit untuk menambah modal atau investasi dengan tingkat bunga yang rendah.

Berdasarkan pernyataan-pernyataan di atas, maka hipotesis ketiga penelitian ini adalah :

Ho3: BI rate berpengaruh signifikan terhadap volume perdagangan saham pada perusahaan sektor perbankan BUMN di Bursa Efek Indonesia.Ha3: BI rate tidak berpengaruh signifikan terhadap volume perdagangan saham pada perusahaan sektor perbankan BUMN di Bursa Efek Indonesia.

\section{Pengaruh inflasi, kurs, dan BI Rate terhadap volume perdagangan saham perbankan BUMN yang terdaftar di Bursa Efek Indonesia.}

Para pemilik modal (investor) di pasar modal dalam melakukan keputusan investasinya mempertimbangkan resiko sistematis, yang berarti investor melihat kondisi faktor makro ekonomi di Negara tujuan investasinya (Jonathan, 2013:144).

Berdasarkan pernyataan di atas, maka hipotesis keempat (H4) penelitian ini adalah :

Ho4 : Inflasi, kurs, dan BI rate secara simultan berpengaruh signifikan terhadap volume perdagangan saham pada perusahaan sektor perbankan BUMN di Bursa Efek Indonesia.
Ha4 : Inflasi, kurs, dan BI rate secara simultan tidak berpengaruh signifikan terhadap volume perdagangan saham pada perusahaan sektor perbankan BUMN di Bursa Efek Indonesia.

Koefisien Determinasi $\left(R^{2}\right)$

Besarnya nilai $R^{2}$ digunakan untuk mengetahui besarnya sumbangan variabel independen yang diteliti terhadap variabel dependen. Jika $R^{2}$ semakin besar (mendekati satu), maka sumbangan variabel independen terhadap variabel dependen semakin besar. Sebaliknya apabila $R^{2}$ semakin kecil (mendekati nol), maka besarnya sumbangan variabel independen terhadap variabel dependen semakin kecil. Jadi besarnya $R^{2}$ berada diantara $0-1$ atau $0>R^{2}<1$ (Ghozali,2009:87).

Hasil Analisis Pengaruh Inflasi, Kurs, Dan BI Rate Terhadap Volume Perdagangan Saham Perbankan BUMN

\section{Teknik Pemilihan Model}

Selanjutnya untuk memilih metode estimasi yang tepat diantara ketiga jenis metode, diperlukan beberapa tahapan pengujian, yaitu:

a. Uji Chow

Tabel 1. Hasil Uji Chow

\begin{tabular}{ll}
\hline Nilai prob $>$ F & 0.0002 \\
Hasil & Tolak Ho \\
\hline Sumber: Data sekunder diolah
\end{tabular}

\section{b.Uji Hausman}

Tabel 2. Hasil Uji Hausman

\begin{tabular}{ll}
\hline Nilai prob $>$ chi2 & 1.0000 \\
Hasil & Terima Ho \\
\hline Sumber: Data sekunder diolah
\end{tabular}

\section{Uji Asumsi Klasik}

\section{Multikolinearitas}

Tabel 3. Hasil Uji Multikolinearitas

\begin{tabular}{lll}
\hline Variable & VIF & 1/VIF \\
\hline Sukubungabi & 3.15 & 0.31776 \\
Kursusd & 2.58 & 0.387613 \\
Inflasi & 1.43 & 0.696921 \\
\hline Mean VIF & 2.39 & \\
\hline
\end{tabular}

Sumber: Data sekunder diolah 


\section{Hasil Regresi Data Panel dengan Random Effect}

Tabel 4. Hasil Regresi Data Panel dengan Random Effect

\begin{tabular}{lllc}
\hline $\begin{array}{l}\text { Prob }>\text { chi2 } \\
\text { R-squared } \\
\text { overall }\end{array}$ & & & 0.0051 \\
\hline Volume & Coef. & $\mathbf{z}$ & $\mathbf{P}>\mathbf{z}$ \\
\hline Inflasi & $8.56 \mathrm{E}+08$ & 0.64 & 0.524 \\
Kursusd & -40246.14 & -2.68 & 0.007 \\
Sukubungabi & $1.13 \mathrm{E}+10$ & 2.9 & 0.004 \\
$\quad$ cons & $1.91 \mathrm{E}+08$ & 1.21 & 0.228 \\
\hline Sumber: Data sekunder diolah & &
\end{tabular}

\section{Pembahasan}

\section{Teknik Pemilihan Model}

a. Uji Chow

Dari tabel 1 diatas dapat dilihat nilai prob $>F$ sebesar 0.0002 lebih kecil dari alfa. Jadi dapat disimpulkan bahwa Fixed Effect yang lebih tepat digunakan dalam penelitian ini.

\section{b. Uji Hausman}

Dari tabel 2 diatas dapat dilihat nilai prob $>$ chi2 sebesar 1.0000 lebih besar dari alfa. Jadi dapat disimpulkan bahwa Random effeck yang lebih tepat digunakan dalam penelitian ini.

\section{Uji Asumsi Klasik}

\section{Multikolinearitas}

Dari hasil regresi data, terlihat nilai tolerance dan nilai variance inflation factor (VIF) dari variabel-variabel indenpenden sebagai berikut:

- Nilai tolerance variabel indenpenden BI rate sebesar 0.31 , dimana nilai $0.31>10 \%$, dan nilai variance inflation factor (VIF) variabel independen BI rate sebesar 3.15, dimana nilai 3.15 $<10$.

- Nilai tolerance variabel independen kurs sebesar 0.38 , dimana nilai $0.38>10 \%$, dan nilai variance inflation factor (VIF) variabel independen kurs sebesar 2.58, dimana nilai $2.58<10$.

- Nilai tolerance inflasi sebesar 0.69 , dimana nilai $0.69>10 \%$, dan nilai variance inflation factor (VIF) variabel independen inflasi sebesar 1.43, dimana nilai $1.43<10$.

Maka dapat disimpulkan bahwa semua variabel independen terbebas dari masalah multikolinearitas dan model dapat digunakan atau bersifat BLUE (Best Linear Unbiased Estimator).

\section{Hasil Regresi Data Panel dengan Random Effect}

\section{Uji Hipotesis}

\section{a. Uji t ( parsial )}

Dari hasil regresi tabel 4 diatas dapat dilihat:

\section{1)Pengaruh Inflasi Terhadap Volume Perdagangan Saham Perbankan BUMN yang Terdaftar di Bursa Efek Indonesia.}

Berdasarkan hasil uji t diketahui nilai koefisien inflasi sebesar 8.56E08, dengan tingkat signifikansinya sebesar 0.524 lebih besar dari 0.05. Maka hipotesis pertama (Ho1) ditolak dan Ha1 diterima, yaitu inflasi tidak berpengaruh signifikan terhadap volume perdagangan saham pada perusahaan sektor perbankan BUMN di Bursa Efek Indonesia. Sehingga dapat dikatakan bahwa secara parsial inflasi berpengaruh positif dan tidak signifikan terhadap volume perdagangan saham pada perusahaan sektor perbankan BUMN di Bursa Efek Indonesia. Artinya ketika inflasi mengalami peningkatan maka akan meningkatkan volume perdagangan saham pada perusahaan sektor perbankan, begitu pula sebaliknya.

Hasil ini berbanding terbalik dengan teori, dimana inflasi yang tidak stabil berdampak negatif terhadap kondisi sosial ekonomi masyarakat. Inflasi yang tidak stabil akan menciptakan ketidakpastian bagi pelaku ekonomi dalam mengambil keputusan berinvestasi, konsumsi, dan produksi dan pada akhirnya akan menyebabkan menurunnya pertumbuhan ekonomi (Bank Indonesia, 2016). Yang berarti bahwa inflasi berpengaruh negatif dan signifikan terhadap volume perdagangan saham.

Penelitian ini menunjukkan bahwa kondisiinflasi tidak berpengaruh signifikan terhadap volume perdagangan saham. Hasil ini sesuai dengan penelitian yang dilakukan oleh Jonathan (2013) dan Maryanne (2009) dimana hasil penelitiannya diperoleh bahwa tidak ada pengaruh yang signifikan antara inflasi terhadap volume perdagangan saham pada perusahaan sektor perbankan BUMN di Bursa Efek Indonesia.

Hal ini dikarenakan selama periode penelitian, inflasi berada dalam kategori inflasi ringan atau kurang dari $10 \%$ yang berdampak positif terhadap meningkatnya jumlah investasi. Meningkatnya jumlah investasi ini dikarenakan para investor di pasar modal lebih memilih untuk menginvestasikan kelebihan dananya di pasar modal dibandingkan dengan menyimpannya dalam bentuk deposito. Jika investor menyimpan dananya dalam bentuk deposito, maka belum tentu tingkat bunga deposito lebih tinggi dibandingkan dengan inflasi pada tahun tersebut. Selain hal tersebut, pemerintah juga berusaha untuk meyakinkan 
masyarakat bahwa inflasi akan tetap berada pada titik stabil, dengan melakukan prediksi atau menentukan target inflasi untuk tahun berikutnya. Hal ini berdampak pada keyakinan investor bahwa perekonomianpun akan tetap tetap stabil. Sehingga hal ini menyebabkan investor lebih tertarik untuk melakukan investasi di pasar modal guna memperoleh keuntungan jangka panjang. Berikut tabel perbandingan target inflasi dan aktual inflasi tahun 2011-2015.

Tabel 5. Perbandingan Target Inflasi dan Aktual Inflasi Tahun 2011-2015.

\begin{tabular}{lll}
\hline Tahun & Target & Aktual \\
\hline 2011 & $5 \pm 1 \%$ & $3.79 \%$ \\
2012 & $4.5 \pm 1 \%$ & $4.30 \%$ \\
2013 & $4.5 \pm 1 \%$ & $8.38 \%$ \\
2014 & $4.5 \pm 1 \%$ & $8.36 \%$ \\
2015 & $4 \pm 1 \%$ & $6 \%$ \\
Sumber: www.bi.go.id &
\end{tabular}

2)Pengaruh Kurs Terhadap Volume Perdagangan Saham Perbankan BUMN yang Terdaftar di Bursa Efek Indonesia.

Berdasarkan hasil uji t diketahui nilai koefisien kurs sebesar -40246.14, dengan tingkat signifikansinya sebesar 0.007 lebih kecil dari 0.05. Maka hipotesis kedua (Ho2) diterima dan $\mathrm{Ha} 2$ ditolak, yaitu kurs berpengaruh signifikan terhadap volume perdagangan saham pada perusahaan sektor perbankan BUMN di Bursa Efek Indonesia. Sehingga dapat dikatakan bahwa secara parsial kurs berpengaruh negatif dan signifikan terhadap volume perdagangan saham pada perusahaan sektor perbankan BUMN di Bursa Efek Indonesia. Artinya ketika kurs mengalami peningkatan maka akan menurunkan volume perdagangan saham, begitu pula sebaliknya.

Menurut Sukirno dalam Triyono (2008:157), ketika mata uang rupiah melemah terhadap dollar AS artinya terjadi penurunan harga rupiah terhadap harga dollar AS atau disebut dengan depresiasi, maka akan membuat harga barang-barang domestik menjadi lebih murah bagi pihak luar negeri. Sedangkan apresiasi rupiah terhadap dollar AS membuat harga barang-barang domestik menjadi lebih mahal bagi pihak luar negeri. Artinya bahwa kurs berpengaruh negatif dan signifikan terhadap volume perdagangan saham.

Penelitian ini menunjukkan bahwa kondisi kurs yang tinggi akan menyebabkan jumlah volume perdagangan saham menurun atau sebaliknya. Pada saat nilai kurs terdepresiasi, investor akan banyak melakukan transaksi di bursa saham karena nilai rupiah sedang menguat atau appresiasi, disamping itu biasanya para investor juga cenderung berinvestasi di pasar valas (melakukan pembelian mata uang dollar untuk memperoleh keuntungan jangka pendek). Sehingga pada saat terjadi lonjakan kenaikan kurs, jumlah transaksi di bursa efek akan cenderung menurun ataupun stagnan/tetap.

Penelitian sebelumnya yang dilakukan oleh Pramaditya (2008) juga menunjukkan hasil yang sama yaitu, ada pengaruh negatif dan signifikan antara kurs terhadap volume perdagangan saham pada perusahaan sektor perbankan BUMN di Bursa Efek Indonesia.

3) Pengaruh BI Rate Terhadap Volume Perdagangan Saham Perbankan BUMN yang Terdaftar di Bursa Efek Indonesia.

Berdasarkan hasil uji t diketahui nilai koefisien BI rate sebesar 1.13E10, dengan tingkat signifikansinya sebesar 0.004 lebih kecil dari 0.05. Maka hipotesis ketiga (Ho3) diterima dan $\mathrm{Ha} 3$ ditolak, yaitu $\mathrm{BI}$ rate berpengaruh signifikan terhadap volume perdagangan saham pada perusahaan sektor perbankan BUMN di Bursa Efek Indonesia. Sehingga dapat dikatakan bahwa secara parsial BI rate berpengaruh positif dan signifikan terhadap volume perdagangan saham pada perusahaan sektor perbankan BUMN di Bursa Efek Indonesia. Artinya ketika BI rate mengalami peningkatan maka volume perdagangan saham juga akan meningkat, begitu pula sebaliknya.

Menurut Maryanne (2009:44) dimana ketika suku bunga tinggi akan menyebabkan tingginya volume tabungan masyarakat. Semakin tingginya tingkat suku bunga deposito yang ditawarkan bank, maka akan mendorong masyarakat untuk lebih banyak menabung dibandingkan dengan menyimpan uangnya dalam bentuk saham. Hal ini berarti bahwa BI rate berpengaruh negatif terhadap volume perdagangan saham.

Hasil penelitian ini menunjukkan bahwa BI rate berpengaruh positif dan signifikan terhadap volume perdagangan saham perbankan. Penelitian sebelumnya yang dilakukan oleh Pramaditya (2008) dan Jonathan (2013) juga menunjukkan ada pengaruh positif dan signifikan antara BI rate terhadap volume perdagangan saham pada perusahaan sektor perbankan BUMN di Bursa Efek Indonesia.

Hal ini dikarenakan suku bunga yang tinggi akan menyebabkan semakin meningkatnya nilai mata uang asing atau dengan kata lain terjadi appresiasi terhadap Dollar. Karena terjadinya appresiasi Dollar maka jumlah saham yang mampu dibeli oleh investor asing akan semakin banyak atau kemampuan investor untuk membeli saham semakin tinggi. Dalam hal ini BI rate 
berpengaruh positif dan signifikan terhadap volume perdagangan saham perbankan BUMN yang terdaftar di Bursa Efek Indonesia.

\section{b. Uji F (simultan)}

Dari hasil regresi tabel 4 diatas dapat dilihat:

Pengaruh Inflasi, Kurs, Dan BI Rate Terhadap Volume Perdagangan Saham Perbankan BUMN yang Terdaftar di Bursa Efek Indonesia.

Berdasarkan hasil uji F diketahui inflasi, kurs, dan BI rate berpengaruh signifikan terhadap volume perdagangan saham, dengan tingkat signifikansi sebesar 0.0499 lebih kecil dari 0.05. Maka hipotesis keempat (Ho4) diterima, yaitu inflasi, kurs, dan BI rate secara simultan berpengaruh signifikan terhadap volume perdagangan saham pada perusahaan sektor perbankan BUMN di Bursa Efek Indonesia. Sehingga dapat dikatakan bahwa secara simultan ada pengaruh yang signifikan antara inflasi, kurs, dan BI rate terhadap volume perdagangan saham pada perusahaan sektor perbankan BUMN di Bursa Efek Indonesia. Adanya pengaruh yang signifikan ini mengindikasikan bahwa besar kecilnya inflasi, kurs, dan BI rate secara simultan pada periode bulanan tahun 2011 - 2015 berdampak besar pada naik turunnya volume perdagangan saham.

Hasil dari penelitian ini menjelaskan bahwa para pemilik modal (investor) di pasar modal dalam melakukan keputusan investasinya mempertimbangkan resiko sistematis, yang berarti investor melihat kondisi faktor makro ekonomi di Negara tujuan investasinya, dalam hal ini Indonesia (Jonathan, 2013:144).

Hasil penelitian ini sesuai dengan penelitian yang dilakukan oleh Pramaditya (2008) dan Jonathan (2013) dimana hasil penelitiannya diperoleh bahwa inflasi, kurs, dan BI rate secara bersama-sama berpengaruh signifikan terhadap volume perdagangan saham.

\section{c. Koefisien Determinasi $\left(R^{2}\right)$}

Nilai $R$ Square overall sebesar 0.0481 , yang artinya ketiga variabel bebas (inflasi, kurs, dan BI rate) mempunyai hubungan kausalitas dengan volume perdagangan saham perbankan sebesar $4.81 \%$ dan sisanya sebesar $95.19 \%$ dijelaskan oleh variabel lainnya yang tidak diteliti dalam penelitian ini. Nilai $95.19 \%$ diperoleh dari $100 \%-4.81 \%$. Variabel independen lainya yang dapat menjelaskan volume perdagangan saham yaitu harga saham (Tandelilin dalam Sari, 2012:109), return saham (kant, 2011:01), dan suku bunga SBI (Pramaditya, 2008:60).

\section{Kesimpulan}

Berdasarkan hasil analisis yang telah dilakukan peneliti mengenai pengaruh inflasi, nilai tukar (kurs) USD, dan BI rate terhadap volume perdagangan saham perbankan yang terdaftar di Bursa Efek Indonesia (BEI), maka dapat ditarik kesimpulan sebagai berikut:

1. Secara parsial tidak ada pengaruh yang signifikan antara inflasi terhadap volume perdagangan saham pada perusahaan sektor perbankan BUMN di Bursa Efek Indonesia.

2. Secara parsial ada pengaruh yang signifikan antara kurs terhadap volume perdagangan saham pada perusahaan sektor perbankan BUMN di Bursa Efek Indonesia.

3. Secara parsial ada pengaruh yang signifikan antara BI rate terhadap volume perdagangan saham pada perusahaan sektor perbankan BUMN di Bursa Efek Indonesia.

4.Secara simultan ada pengaruh yang signifikan antara inflasi, kurs, dan BI rate terhadap volume perdagangan saham pada perusahaan sektor perbankan BUMN di Bursa Efek Indonesia.

\section{Saran}

Berdasarkan hasil analisis yang telah dilakukan peneliti mengenai pengaruh inflasi, nilai tukar (kurs) USD, dan $\mathrm{BI}$ rate terhadap volume perdagangan saham perbankan BUMN yang terdaftar di Bursa Efek Indonesia (BEI), maka peneliti menyarankan sebagai berikut:

1. Bagi pemerintah, dari hasil penelitian ini menunjukkan kurs dan BI rate berpengaruh signifikan terhadap volume perdagangan saham perbankan BUMN yang terdaftar di Bursa efek Indonesia maka pemerintah diharapkan dalam menetukan kebijakan - kebijakannya lebih memperhatikan kestabilan kurs dan BI rate agar volume perdagangan saham perbankan BUMN tetap stabil.

2. Bagi peneliti selanjutnya yang akan melakukan penelitian serupa agar menambah variabel independen lainnya yang dapat menjelaskan volume perdagangan saham perbankan.

3. Bagi peneliti selanjutnya agar dapat meneliti dari sektor atau indeks lainnya yang berbeda, dengan jumlah data yang lebih banyak, dan jumlah tahun pengamatan yang lebih panjang agar memberikan hasil yang baik. 


\section{Daftar Pustaka}

Alaganar, V. T. (2003). An International Study of Causality-in-Variance: Interest Rate and Financial Sector Returns. Journal Of Economics And Finance. VOL 27. NO.01, 39-55.

Bakhromov, N. (2011). The Exchange Rate Volatility and the Trade Balance: Case of Uzbekistan. Journal of Applied Economics and Business Research, 1(3): 149- 161.

Ghozali, I. (2009). Aplikasi Analisis Multivariate Dengan Program SPSS. Semarang: Universitas Diponegoro.

Husen, S. (2011). Pengaruh Pengeluaran Agregat Dalam Mendorong Pertumbuhan Produk Domestik Bruto Dan Implikasinya Pada Kesejahteraan Sosial. Jurnal Ekonomi Pembangunan Vol. 12, No.1, ISSN: 1411-6081, 130-158

Jonathan, T. I. (2013). Analisa Pengaruh Inflasi, Suku Bunga dan Kurs Terhadap Volume Transaksi Pada Index LQ45. FINESTA Vol. 1, No. 2 , 141144.

Kant, R. (2011). Testing Of Relationship Between Stock Return And Trading Volume In India. International Journal of Multidisciplinary Research, Vol.1 Issue 6, ISSN 22315780 , 371393.

Maryanne, D. M. (2009). Pengaruh Nilai Tukar Rupiah, Suku Bunga SBI, Volume Perdagangan Saham, Inflasi Dan Beta Saham Terhadap Harga Saham (Studi Empiris Pada Perusahaan Sektor Perbankan Di Bursa Efek Indonesia Periode 2004 - 2007). Tesis. Semarang: Program Studi Magister Manajemen Program Pascasarjana Universitas Diponegoro .

Mubarik, F. \&. Javid, A. Y. (2009). Relationship Between Stock Return, Trading Volume And Volatility: Evidence From Pakistani Stock Market. Asia Pacific Journal of Finance and Banking Research Vol. 3. No. 3, 1-17.

Nasution, C. L. (2014). Pengaruh Volume Perdagangan Saham, Tingkat Inflasi, Nilai Kurs Dollar As (USD) Dan Tingkat Suku Bunga SBI Terhadap Harga Saham Perusahaan Properti Yang Tercatat Di Bursa Efek Indonesia (BEI). Skripsi. Bengkulu : Jurusan Manajemen Fakultas Ekonomi Dan Bisnis Universitas Bengkulu.

Pramaditya, R. (2008). Pengaruh SBI, Nilai Kurs As (USD), Inflasi Terhadap Volume Perdagangan Saham Yang Terdaftar Di Bursa Efek Indonesia Tahun 2004-2006. Skripsi. Jakarta: Fakultas Ekonomi Universitas Mercu Buana.

Samuelson. (2004). Ilmu Makro Ekonomi. Jakarta: Media Global Edukasi.
Sari, N. (2012). Pengaruh Harga Saham, Tingat Bunga Deposito Dan Capital Gain/Loss Terhadap Volume Transaksi Saham Pada Perusahaan LQ45 Yang Go-Public Di Bursa Efek Indonesia. Skripsi. Pekanbaru: Fakultas Ekonomi dan Ilmu Sosial Universitas Islam Negeri Sultan Syarif Kasim Riau.

Setiawati, A. K. \& Setiawan. (2012). Pemodelan Persentase Penduduk Miskin di Jawa Timur dengan Pendekatan Ekonometrika Panel Spasial. Jurnal Sains dan Seni Its Vol. 1, No. 1, ISSN: 2301-928X

Setyowati, U. (2007). Analisis Faktor-Faktor Yang Mempengaruhi Volume Perdagangan Saham Perbankan di Pasar Modal Pada Bursa Efek Jakarta. Skripsi. Surakarta: Fakultas Ekonomi Universitas Muhammadiyah Surakarta.

Sugiyono. (2013). Metode Penelitian Kuantitatif, Kualitatif, dan $R \& D$. Bandung: Alfabeta.

Sugiyono. (2016). Metode Penelitian Kuantitatif, Kualitatif, dan R\&D. Bandung: Alfabeta.

Suwardi, A. (2011). Stata: Tahapan Perintah (Syntax) Data Panel. Depok: Lab. Komputasi Departemen Ilmu Ekonomi Gedung Departemen Ilmu Ekonomi-FEUI Lt. 1.

Triyono. (2008). Analisis Perubahan Kurs Rupiah Terhadap Dollar Amerika. Jurnal Ekonomi Pembangunan, Vol. 9, No. 2 , 156-167.

Widarjono, Agus. 2009. "Ekonometrika pengantar dan aplikasinya”. Ekonisia. Yogyakarta.

http://www.artikelsains.com/2015/01 dampak-inflasidan-cara-cara-mengatasi.html? $\mathrm{m}=1$ diakses pada 28 April 2017

http://matacorpora.com/index.php?route=product/categ ory\&path=65_103 diakses pada 09 April 2017

http://www.bi.go.id/id/moneter/birate/penjelasan/Contents/Default.aspx diakses pada 18 November 2016

http://www.bi.go.id/id/moneter/informasikurs/transaksi-bi/Default.aspx diakses pada 18 November 2016

http://www.bi.go.id/id/moneter/inflasi/bi-daninflasi/Contents/Default.aspx diakses pada 18 November 2016

https://finance.yahoo.com diakses pada 18 November 2016

http:/www.sahamok.com/emiten/sektor-keuangan/subsektor-bank/ diakses pada 18 November 2016

https://m.tempo.co/topik/masalah/2096/inflasi diakses pada 28 April 2017 